\title{
Use of stable carbon isotope ratios to compare plant material and potential consumers in a seagrass bed and a kelp bed in Nova Scotia, Canada
}

\author{
R. L. Stephenson ${ }^{1,3, ~ ", ~ F . ~ C . ~} \operatorname{Tan}^{2}$ \& K. H. Mann ${ }^{3}$ \\ ${ }^{1}$ Department of Biology, Dalhousie University, Halifax, Nova Scotia B3H 4J1, Canada \\ ${ }^{2}$ Atlantic Oceanographic Laboratory and ${ }^{3}$ Marine Ecology Laboratory, \\ Dept. of Fisheries and Oceans, Bedford Institute of Oceanography, P.O. Box 1006, Dartmouth, Nova Scotia B2Y 4A2, Canada
}

\begin{abstract}
In an attempt to quantify the importance of macrophytes to coastal food webs, stable carbon isotope ratios $\left(\delta^{13} \mathrm{C}\right)$ of animals occurring in a Zostera marina (seagrass) bed were compared with those in a nearby Laminaria longicruris (kelp) bed in St. Margaret's Bay, Nova Scotia. Only 1 species, a small herbivorous gastropod, Lacuna vincta, showed a significant difference in $\delta^{13} \mathrm{C}$ between the 2 habitats. It was concluded that neither the remaining herbivores, the filter feeders, nor their predators derived a significant amount of carbon from the $Z$. marina; this reinforces the view that seagrass carbon plays a relatively minor part in the flux through the invertebrate food webs of seagrass beds. Controlled laboratory experiments showed that predators (lobsters) and filter feeders (oysters) assumed tissue isotopic values that were significantly less negative than the diets on which they had been grown, and that the most probable mechanism producing this effect was selective assimilation of compounds from the diet. Amphipods Gammarus lawrencianus and isopods Idotea baltica did not show such a shift, possibly because their diets were homogeneous and therefore did not provide an opportunity for selective assimilation of ${ }^{13} \mathrm{C}$-enriched compounds. No systematic shift in $\delta^{13} \mathrm{C}$ appeared to be associated with plant degradation and the formation of detritus.
\end{abstract}

\section{INTRODUCTION}

The hypothesis that vascular marine plants such as marsh grasses, seagrasses and mangroves are important contributors to the productivity of food webs in coastal waters has recently been challenged from a number of directions (Boesch \& Turner 1984, Mann in press). Nixon (1980) summarized the evidence for and against the view that large amounts of organic matter are exported from salt marshes and subsequently used in estuarine food webs and concluded that, in general, this is not true. The long series of experiments by K. R. Tenore and his colleagues (e.g. Tenore \& Hanson 1980, Findlay \& Tenore 1982) showed that a detritivorous

\footnotetext{
- Present address: Dept. of Fisheries and Oceans, St. Andrews Biological Station, St. Andrews, New Brunswick E0G 2X0, Canada
}

(c) Inter-Research/Printed in F. R. Germany invertebrate (Capitella capitata) can use algal detritus much more efficiently than vascular plant detritus. Incorporation of the latter into invertebrate food webs depends on a lengthy process of conditioning by microorganisms, during which much of the original plant material may be oxidized by the microbes and lost to the food chain (Mann in press).

The use of the ratio of stable carbon isotopes $\left({ }^{13} \mathrm{C} /{ }^{12} \mathrm{C}\right)$ as a marker in food web studies led Haines $(1976 \mathrm{a}, \mathrm{b})$ to conclude that many invertebrates living in and around salt marshes derive most of their carbon from algal sources rather than from the marsh grass Spartina. Thayer et al. (1978), using the same technique, concluded that seagrass carbon plays 'a significant but not dominant role' in the food web of a Zostera marina bed in North Carolina. Similar conclusions were reached by McConnaughey \& McRoy (1979) with respect to seagrass beds in Alaska. Ratios of ${ }^{13} \mathrm{C} /{ }^{12} \mathrm{C}$ cannot be 
used to distinguish macroalgal carbon from phytoplankton carbon because they tend to overlap (Fry \& Sherr 1984, Stephenson et al. 1984) but detailed studies of the utilization of macroalgae by consumers (e.g. Tenore \& Hanson 1980, Stuart 1982) have shown that the fresh algal material or its detritus is readily and efficiently incorporated into coastal food webs.

The relative contribution of algal and vascular plant types to coastal food webs remains a significant question in temperate Atlantic coastal areas where both macroalgae (especially kelps) and vascular plants (seagrass, marsh grass) have been shown to be very productive and hypothesized as contributing substantially to coastal secondary production (e.g. Mann 1982). In this study, the ${ }^{13} \mathrm{C} /{ }^{12} \mathrm{C}$ ratio was used to compare plant material and potential consumers in a seagrass (Zostera marina) bed and kelp (Laminaria longicruris) bed situated in the same bay. An earlier study (Stephenson et al. 1984) had documented the variability in space and time of the ${ }^{13} \mathrm{C} /{ }^{12} \mathrm{C}$ ratio of these 2 macrophytes. We now proceeded to compare the ${ }^{13} \mathrm{C} /{ }^{12} \mathrm{C}$ ratio of a number of species that occur in both habitats, to see to what extent they appeared to be using the macrophyte carbon from the plants surrounding them. The animals studied include grazers (Lacuna vincta, Littorina littorea and Strongylocentrotus droebachiensis), filter feeders (Mytilus edulis and Modiolus modiolus) and carnivores (Asterias vulgaris, Cancer irroratus and Homarus americanus).

As an aid to interpreting the results of the field study and in light of the need for elucidation of the mechanisms of organic matter transfer in the coastal marine system in general (see Simenstad \& Wissmar 1985), we carried out laboratory studies on the relation between the isotopic composition of animals and their food. We reared a variety of animals (depending upon the availability of newly hatched juveniles) for 3 to 4 mo on food of known isotope ratio; using amphipods and isopods as examples of herbivore/detritus feeders, oysters as filter feeders and lobsters as carnivores. Earlier experimental results of animals grown on diets of known carbon isotope composition (DeNiro \& Epstein 1978, Haines \& Montague 1979, Macko et al. 1982) had led to the conclusion that the average ${ }^{13} \mathrm{C} /{ }^{12} \mathrm{C}$ ratio of the combined tissues of an animal is usually within $0.7 \%$ of that of its food (Fry \& Sherr 1984). However, this result was the average from not only aquatic animals but also terrestrial animals and microbes. Moreover, with one exception (Haines \& Montague 1979) there had not been systematic studies of the effect of feeding one species of animal a range of food of markedly different isotope ratios.

Since it is the fate of most macrophyte production in the sea to pass through a detritus phase before being consumed by animals, we also studied the changes in
${ }^{13} \mathrm{C} /{ }^{12} \mathrm{C}$ ratio in seagrass, seaweed and marsh grass detritus, incubated under a range of natural and laboratory conditions.

\section{METHODS}

Samples of animals were collected from a kelp bed (Laminaria longicruris) and an eelgrass bed (Zostera marina) located about $0.6 \mathrm{~km}$ apart at a depth of $10 \mathrm{~m}$ in St. Margaret's Bay on the Atlantic coast of Nova Scotia. The area of each bed was approximately $3 \times 10^{4} \mathrm{~m}^{2}$. Snails Lacuna vincta and Littorina littorea and the urchin Strongylocentrotus droebachiensis (kelp bed only) were attached to the macrophytes at the time of capture. The mussel Modiolus modiolus, the starfish Asterias vulgaris, the crab Cancerirroratus and the lobster Homarus americanus were taken from the sea floor. The mussel Mytilus edulis was taken from mooring lines 1 to $2 \mathrm{~m}$ above the macrophytes. Tissues were excised (muscle avoiding gut contents from molluscs and crustaceans; sections of echinoderms) and frozen.

For analysis, samples were freeze-dried and the carbon isotope composition analyzed on a Nuclide 6-60 RMS mass spectrometer, following the procedures of Tan \& Strain $(1979,1983)$. The results are reported in $\delta^{13} \mathrm{C}$ notation with respect to the PDB standard. Precision was assessed using homogenized standards of Zostera marina $(\overline{\mathrm{X}}=-7.4 \% ; \mathrm{SD}=0.22, \mathrm{n}=14$ ) and Laminaria longicruris $(\overline{\mathrm{X}}=-15.5 \%$; $\mathrm{SD}=0.18$, $\mathrm{n}=17$ )

Amphipods Gammarus lawrencianus and isopods Idotea baltica were each grown $\sim 12 \mathrm{wk}$ on 7 diets. Five were commercial cereals (Heinz mixed, Heinz rice, Heinz oatmeal, Pablum and Nabisco 'cream of wheat') used without modification. The others were previously live kelp Laminaria longicruris and marsh grass Spartina alterniflora which had been freezedried, leached for $24 \mathrm{~h}$ in seawater, freeze-dried again, ground and sieved to a particle size $<1 \mathrm{~mm}$. Animals were maintained from the time of hatching in static cultures of filtered seawater at room temperature $\left(\sim 20^{\circ} \mathrm{C}\right)$ in darkness. Water was changed, the culture tank rinsed well, and food replaced every second day. Animals were kept without food for $24 \mathrm{~h}$ to clear their guts prior to harvesting, and analysis was conducted on homogenized whole specimens.

Oyster spat were reared on algae (Chaetoceros gracilis or Isochrysis galbana T-iso) that had had their $\delta^{13} \mathrm{C}$ values manipulated by culturing under nutrient stress in cultures bubbled with commercially bottled $\mathrm{CO}_{2}$; this gave a range of $\delta^{13} \mathrm{C}$ of -43.0 to $-50.7 \%$, which is considerably more negative than would be 
found in natural phytoplankton. Oysters were kept without food for $24 \mathrm{~h}$ prior to harvesting, and body tissues were used for analysis.

Lobster larvae were fed pellets containing differing amounts of crab protein, cornstarch, dextrin, corn oil and cod liver oil, so as to produce a range of caloric values ( 4.7 to $5.4 \mathrm{kcal} \mathrm{g}^{-1}$ dry wt) within a moderate range of $\delta^{13} \mathrm{C}$ values $(-18.0$ to $-20.0 \%)$. Abdominal muscle was used in analysis.

The isotopic change during decomposition and detritus formation was tested in Zostera marina, Laminaria longicruris and the marsh grass Spartina alterniflora. Decomposing Z. marina leaves were collected from the eelgrass bed in St. Margaret's Bay. Samples were taken of dead leaves that were buried in the sediment but still attached to the plant, and compared with samples of live leaves from the same plant.

In laboratory experiments, fresh and freeze-dried pieces of Zostera marina and Laminaria longicruris were incubated for 55 to $60 \mathrm{~d}$ in filtered running seawater. The cultures also contained animals (snails or sea urchins), but material analyzed had not been ingested or physically altered by the animals.

Spartina alterniflora detritus was obtained from decomposition experiments undertaken by Dr. F, $\varnothing$. Andersen and colleagues (Andersen \& Hargrave 1984, Kepkay \& Andersen 1985). In the field experiment, fresh $S$. alterniflora was buried under $1.5 \mathrm{~cm}$ of intertidal sediment in Cobequid Bay, Bay of Fundy, for $125 \mathrm{~d}$. In the laboratory experiment, live and dead S. alterniflora were ground and incubated for $30 \mathrm{~d}$ under $1 \mathrm{~cm}$ of sediment.

\section{RESULTS}

\section{Field data}

The isotope values shown in Fig. 1 for Laminaria longicruris and Zostera marina include the whole seasonal range reported in Stephenson et al. (1984). Even so, there is no overlap between them. Suspended POM samples from the Zostera bed $\left(\delta^{13} \mathrm{C}=-19.1 \%\right.$ ) were very similar in ratio to those from the Laminaria bed $\left(\delta^{13} \mathrm{C}=-18.8 \%\right)$. The values were at the extreme of the range for $L$. longicruris and more negative than pooled or homogenized samples $(-15.5 \%)$; suggesting that phytoplankton, rather than macrophyte detritus, was the source of this material. The sediments in each area had values considerably more negative than those of the macrophytes in the same area (Fig. 1), again suggesting a major input of phytoplankton, which often has a value between -18 and $-25 \%$ (Fry \& Sherr 1984) and has been measured in Nova Scotia waters to be -18.7 to $-19.6 \%$ (Schwinghamer et al. 1983).

The stable isotope ratios of the snail Lacuna vincta collected from the 2 areas were significantly different, suggesting that it feeds directly on the macrophyte material, but no other species examined showed the same kind of separation. There was no significant difference in the $\delta^{13} \mathrm{C}$ values of specimens taken from the Zostera bed and the Laminaria bed in the case of Littorina littorea, Mytilus edulis, Modiolus modiolus, Asterias vulgaris, Cancer irroratus or Homarus americanus (Fig. 1).
Fig. 1. Range in stable carbon isotope composition $\left(\delta^{13} \mathrm{C}, \%\right)$ of organisms and of potential diets from a kelp $(\square)$ and eelgrass ( $\square$ ) bed; St. Margaret's Bay, Nova Scotia

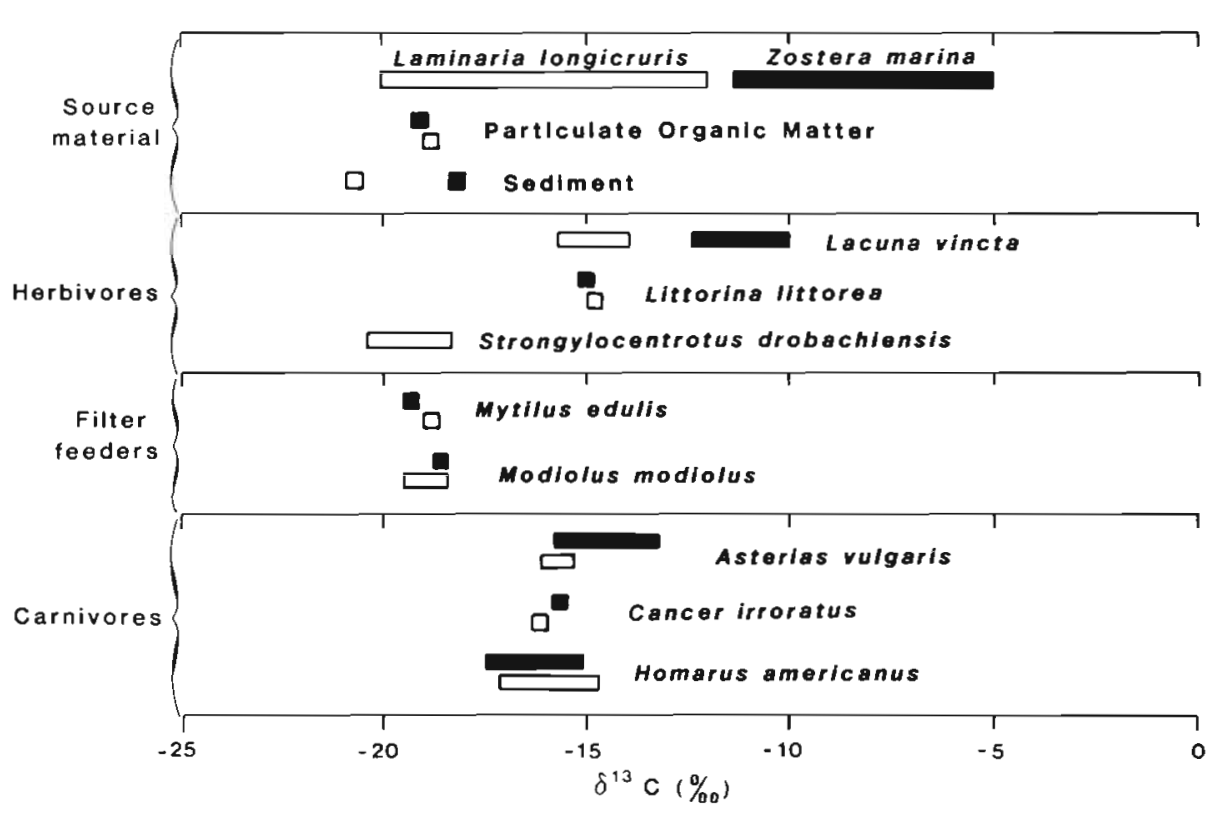




\section{Relation between $\delta^{13} \mathrm{C}$ ratios of animals and their food}

The $\delta^{13} \mathrm{C}$ values of the foods offered to Gammarus lawrencianus and Idotea baltica ranged from -12.8 to $-26.4 \%$. G. lawrencianus reared on Nabisco 'cream of wheat' did not grow and the results were omitted. Plots of stable carbon isotope ratio in the tissues of the animals against the ratios in their food (Fig. 2) show that there were only minor departures from a direct correspondence. There is certainly no evidence for a systematic enrichment in ${ }^{13} \mathrm{C}$. The distribution of points about the line of equal values shows the same pattern for both species; for example, it is true for both $G$. lawrencianus and $I$. baltica that specimens reared on the 2 most negative diets became less negative than their food while those reared on the least negative diet became more negative than their food.

The tendency for animals to be less negative than their food is demonstrated in the case of the oysters grown on food of unusually negative isotope composition (Fig. 3A). The difference in $\delta^{13} \mathrm{C}$ values between the oyster and its food appears to be inversely correlated with the isotope ratio of the food (Fig. 3B).

Lobsters reared on diets of different calorific value

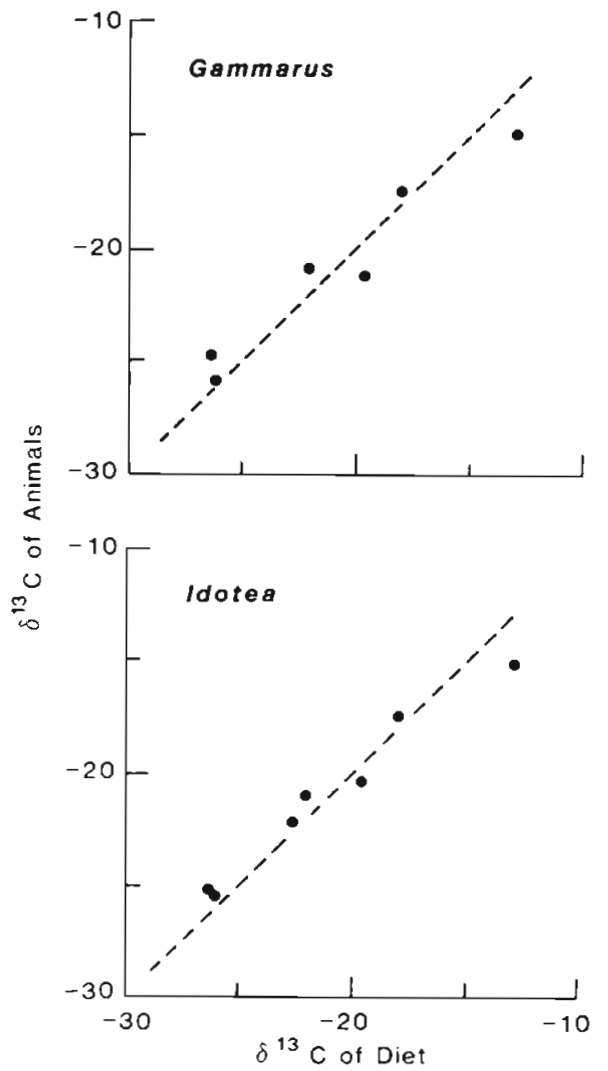

Fig. 2. Gammarus lawrencianus and Idotea baltica. Relation between $\delta^{13} \mathrm{C}$ of individuals and of diets on which they were reared in the laboratory. Dotted line represents $1: 1$ correspondence
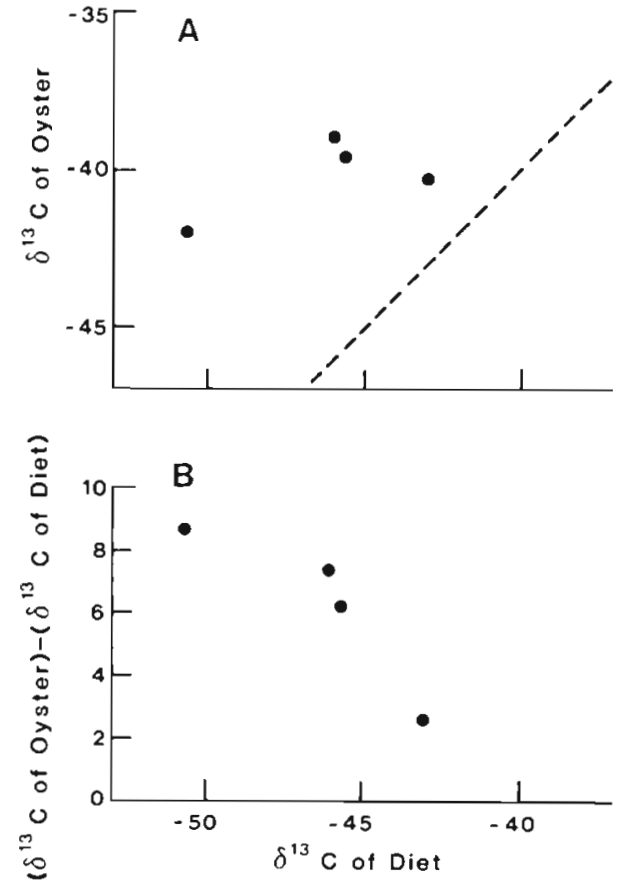

Fig. 3. Ostrea edulis. Relation between (A) $\delta^{13} \mathrm{C}$ of individuals (flesh only) and of diet on which they were grown and (B) shift in isotope composition $\left(\delta^{13} \mathrm{C}\right.$ oyster $-\delta^{13} \mathrm{C}$ diet) and isotope composition of diet. Dotted line represents 1:1 correspondence

all had tissue $\delta^{13} \mathrm{C}$ values that were less negative than the food, thus supporting the prevailing view that a predator is isotopically less negative than its prey. The animal-diet $\delta^{13} \mathrm{C}$ difference ranged from 1.1 to $3.1 \%$, and Fig. 4, the plot of the difference in $\delta^{13} \mathrm{C}$ against the calorific value of food, shows that the shift in $\delta^{13} \mathrm{C}$ was inversely related to the calorific value. Lobsters reared on a high calorie diet are expected to contain more fat, so that this is consistent with the view that lipid storage enriches animals in ${ }^{12} \mathrm{C}$, i.e. leads to a lower ${ }^{13} \mathrm{C} /{ }^{12} \mathrm{C}$ ratio (McConnaughey \& McRoy 1979).

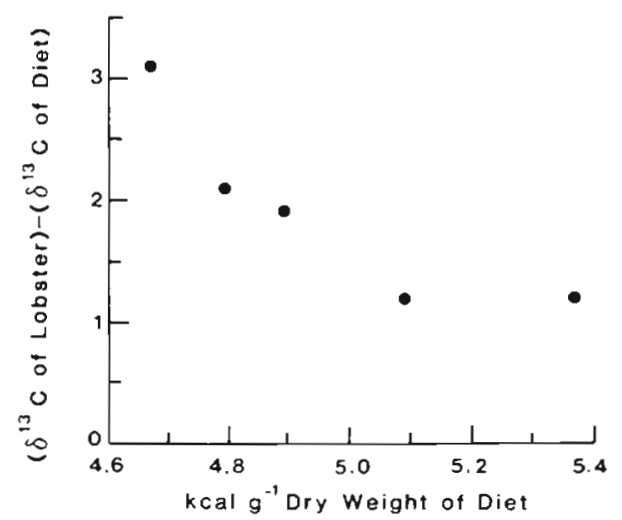

Fig. 4. Homarus americanus. Relation between isotopic shift in lobster tissue $\left(\delta^{13} \mathrm{C}\right.$ lobster $-\delta^{13} \mathrm{C}$ diet) and calorific value of diet 


\section{Isotopic changes during detritus formation}

Both field and laboratory observations confirmed that the process of decomposition per se causes only trivial changes in the $\delta^{13} \mathrm{C}$ ratio of the source plant material. When dead buried leaves of Zostera marina, still attached to the parent plant, were compared with tissue from the tips of the outermost living leaves of that plant, the difference was small (mean $=0.2 \%$; Table 1). Similar small changes (though with a different sign) were found in laboratory incubations of $Z$. marina leaf material. The mean changes in Laminaria Iongicruris were somewhat larger, up to $-1.5 \%$. A single replicate of fresh $L$. longicruris that showed an aberrant value of $-6.5 \%$ has been omitted from the table. Spartina alterniflora detritus changed by only $0.1 \%$ in laboratory incubation and by $1.5 \%$ after $125 \mathrm{~d}$ buried in field sediments (Table 1).

\section{DISCUSSION}

The view that, at least in temperate waters, the carbon of invertebrates living in seagrass beds is derived more from algae than from seagrasses (Thayer et al. 1978, McConnaughey \& McRoy 1979) is supported by the evidence of this study (Fig. 1). The particulate organic matter in suspension and the sediment of the Zostera bed were both much more negative in their $\delta^{13} \mathrm{C}$ than any part of the Zostera marina plants (Stephenson et al. 1984). This indicates an input of phytoplankton or seaweed detritus. Because there were no concentrations of macroalgae within $0.6 \mathrm{~km}$ of the seagrass bed, it seems most probable that phytoplankton composed a large proportion of both suspended and deposited organic carbon. The experiments with detritus formation confirmed that no significant shifts in $\delta^{13} \mathrm{C}$ are to be expected at this level of the food web.

Of the invertebrates examined, only Lacuna vincta had a $\delta^{13} \mathrm{C}$ value overlapping that of the Zostera marina. This small gastropod grazes directly on the living tissue of macrophytes (Johnson 1984) and was observed eating both Laminaria longicruris and $Z$. marina. Littorina littorea had a $\delta^{13} \mathrm{C}$ value considerably more negative than the $Z$. marina, suggesting that it was not feeding on eelgrass. Robertson \& Mann (1982) showed that a related species Littorina neglecta consumed epiphytes and detrital particles from the surface of eelgrass leaves, and not the eelgrass tissue. The habit of the sea urchin Strongylocentrotus droebachiensis of feeding directly on L. longicruris is well documented (e.g. Breen \& Mann 1976); no specimens were found in the Zostera bed.

Value of $\delta^{13} \mathrm{C}$ for the filter feeders Mytilus edulis and Modiolus modiolus taken from the Zostera and Laminaria beds did not differ significantly. It has been

Table 1. Changes in the stable carbon isotope composition $\left({ }^{13} \mathrm{C}\right)$ of Zostera marina, Laminaria longicruris and Spartina alterniflora during detritus formation in field and laboratory experiments

\begin{tabular}{|c|c|c|c|c|c|}
\hline Experiment & $\begin{array}{l}\text { No. of } \\
\text { replicates }\end{array}$ & $\begin{array}{l}\text { Duration } \\
\text { (d) }\end{array}$ & $\begin{array}{c}\text { Initial } \\
\delta^{13} \mathrm{C} \text { value } \\
(\%)\end{array}$ & $\begin{array}{c}\text { Final } \\
\delta{ }^{13} \mathrm{C} \text { value } \\
(\% \circ)\end{array}$ & Change \\
\hline \multicolumn{6}{|l|}{ Zostera marina } \\
\hline $\begin{array}{l}\text { Living leaves compared with dead, buried } \\
\text { leaves attached to same plant (field) }\end{array}$ & 3 & - & $\begin{array}{c}-10.9 \pm 1.0 \\
\text { (living) }\end{array}$ & $\begin{array}{c}-11.1 \pm 1.4 \\
(\text { dead })\end{array}$ & -0.2 \\
\hline $\begin{array}{l}\text { Fresh } Z \text {. marina incubated in running } \\
\text { sea water (lab) }\end{array}$ & 3 & 60 & $-9.7 \pm 0.3$ & $-9.5 \pm 2.4$ & +0.2 \\
\hline $\begin{array}{l}\text { Freeze-dried } Z \text {. marina incubated in } \\
\text { running sea water (lab) }\end{array}$ & 3 & 55 & -7.5 & $-7.4 \pm 0.5$ & +0.1 \\
\hline \multicolumn{6}{|l|}{ Laminaria longicruris } \\
\hline $\begin{array}{l}\text { Fresh } L . \text { longicruris incubated in } \\
\text { running sea water (lab) }\end{array}$ & 4 & 60 & $-17.1 \pm 2.4$ & $-17.5 \pm 2.9$ & -0.4 \\
\hline $\begin{array}{l}\text { Freeze-dried } L \text {. longicruris incubated in } \\
\text { running sea water (lab) }\end{array}$ & 1 & 55 & -17.7 & -19.2 & -1.5 \\
\hline \multicolumn{6}{|l|}{ Spartina alterniflora } \\
\hline $\begin{array}{l}\text { Fresh S. alterniflora buried in sediment } \\
\text { in Bay of Fundy (field) }\end{array}$ & 1 & 125 & -12.9 & -14.4 & -1.5 \\
\hline $\begin{array}{l}\text { Freeze-dried, ground fresh } S \text {. alterniflora } \\
\text { buried in sediment (lab) }\end{array}$ & 1 & 30 & -12.6 & -12.5 & +0.1 \\
\hline $\begin{array}{l}\text { Freeze-dried, ground dead S. alterniflora } \\
\text { buried in sediment (lab) }\end{array}$ & 1 & 30 & -12.7 & -12.6 & +0.1 \\
\hline
\end{tabular}


shown for kelp beds near Cape Town, S. Africa, that mussels ingest and effectively utilize kelp detritus (Seiderer et al. 1982, Stuart 1982) but in our case it seems more probable that the mussels in both sites were obtaining most of their carbon from a common source, namely the phytoplankton, which has a value about $-19 \%$ (Schwinghamer et al. 1983). While the ranges of $L$. longicruris and phytoplankton isotope ratios overlap, particulate matter from $L$. longicruris would be expected to have an isotopic composition with a smaller range around the value of homogenized tissues $(-15.5 \%$ ). The apparent dominance of particulate matter by phytoplankton is consistent with the relative decrease in the predominance of $L$. longicruris in St. Margaret's Bay that has occurred in recent years as a result of sea urchin overgrazing (summarized by Mann 1982).

Sea urchins and mussels are preyed upon by starfish (Asterias vulgaris), crabs (Cancer irroratus) and lobsters (Homarus americanus), whose $\delta^{13} \mathrm{C}$ values are included in Fig. 1. In general, the $\delta^{13} \mathrm{C}$ values of the predators are about $3 \%$ less negative than their prey. It is feasible that this shift could be achieved by the ingestion of a significant number of Lacuna vincta that had been grazing on Zostera marina but this can be ruled out both because $L$. vincta is a very small snail and makes a very small contribution to the biomass of prey organisms and because it spends most of its time on the blades or leaves of the plants, and thus out of reach of benthic predators (Johnson 1984).

A shift to more positive $\delta^{13} \mathrm{C}$ values (i.e. ${ }^{13} \mathrm{C}$ enrichment) as one passes from lower to a higher trophic level has been demonstrated by a number of studies, mainly in offshore food webs (see Table 3 in Fry \& Sherr 1984). McConnaughey \& McRoy (1979) estimated that the shift was $1.5 \%$ for each trophic level; Rau et al. (1983) suggested 0.7 to $1.4 \%$. The mechanisms proposed are (i) more rapid loss of ${ }^{12} \mathrm{CO}_{2}$ during respiration, and (ii) preferential uptake of ${ }^{13} \mathrm{C}$-enriched compounds from the digestive tract. Although there is evidence for both mechanisms, there is no consensus in the literature on the relative contribution of each, or indeed, on the degree of enrichment to be expected at each trophic step, so additional controlled experiments seemed justified.

The results from growing Gammarus lawrencianus and Idotea baltica on a range of foods of known $\delta^{13} \mathrm{C}$ ratio lead to the conclusion that on average there is no systematic difference between the food and the consumer. This suggests that there is no selective loss of ${ }^{12} \mathrm{CO}_{2}$ during respiration and no preferential uptake of ${ }^{13} \mathrm{C}$-enriched compounds from the digestive tract.

Oysters reared on diatoms were all less negative in isotope ratio than their food, the difference being greater in the case of the most negative food. The mean shift was about $6 \%$, which is much greater than the average figures reported in the literature. The flesh only was analyzed and it is possible that the isotope shift was the result of metabolic fractionation in the formation of oyster shell or from selective assimilation. In any case, it does not necessarily follow that such large shifts are to be expected in nature, for the artificially reared diatoms had $\delta^{13} \mathrm{C}$ values considerably more negative than those normally found.

Experimentally reared lobsters were about 1 to $3 \%$ less negative in isotope composition than their food. The diets used differed in their lipid and carbohydrate composition and would have provided ample opportunity for preferential assimilation of ${ }^{13} \mathrm{C}$-enriched foods. The high-calorie diets were those most rich in lipids, which happen to be less ${ }^{13} \mathrm{C}$-rich than proteins and carbohydrates. The intent of the experiment had been to see whether lobsters receiving the high calorie diets accumulated the largest fat reserves, and hence were least ${ }^{13} \mathrm{C}$ enriched. This proved to be the case.

In summary, this study shows that of animals occurring in both a Zostera bed and a Laminaria bed, only one species, a small herbivorous gastropod, showed a significant difference in $\delta^{13} \mathrm{C}$ between the 2 habitats. It was concluded that neither the remaining herbivores, the filter feeders, nor their predators derived a significant amount of carbon from the Zostera marina. The carbon must have been derived from algae, most probably phytoplankton.

Controlled experiments showed that predators (lobsters) and filter feeders (oysters) were significantly less negative than their food, and that the most probable mechanism producing this effect was selective assimilation of ${ }^{13} \mathrm{C}$-enriched compounds from the diet. Amphipods Gammarus lawrencianus and isopods Idotea baltica did not show such a shift, possibly because their diet was homogeneous and did not provide an opportunity for selective assimilation of ${ }^{13} \mathrm{C}$ enriched compounds. No systematic shift in $\delta^{13} \mathrm{C}$ ratio appeared to be associated with the microbial activity involved in detritus formation.

This study reinforces the view of others (Thayer et al. 1978, McConnaughey \& McRoy 1979) that Zostera marina carbon plays a relative minor part in the flux through the invertebrate food webs of seagrass beds or, at least, that the majority of organisms are linked more directly to phytoplankton. Since Laminaria longicruris has a $\delta^{13} \mathrm{C}$ overlapping the range of phytoplankton, it is not possible to use stable carbon isotope techniques to determine how much carbon from the kelp enters the invertebrate food web. Further investigation of the mechanism of isotope fractionation in both macrophytes and consumers is essential before confident interpretation of the results of stable carbon isotope results from coastal food web studies is possible. 
Acknowledgements. We acknowledge the assistance of C. C. Cunningham, D. Pottie and B. E. Welsford in isotope analysis, and C. R. Johnson, S. F. Watts and other members of the diving unit, Biology Department, Dalhousie University, in field work. We are grateful to C. Enright and S. Koshio for providing samples from oyster and lobster cultures and to F. $\varnothing$. Andersen and P. E. Kepkay for providing material from their Spartina alterniflora detritus experiments. This work was funded by the Department of Fisheries and Oceans and by grants from the Natural Sciences and Engineering Research Council of Canada to K. H. Mann. R. L. Stephenson was supported by a post-doctoral fellowship from the Natural Sciences and Engineering Research Council of Canada.

\section{LITERATURE CITED}

Andersen, F. Ø., Hargrave, B. T. (1984). Effects of Spartina detritus enrichment on aerobic/anaerobic benthic metabolism in an intertidal sediment. Mar. Ecol. Prog. Ser. 16: 161-171

Boesch, D. F., Turner, R. E. (1984). Dependence of fishery species on salt marshes: the role of food and refuge. Estuaries 7: 460-468

Breen, P. A., Mann, K. H. (1976). Destructive grazing of kelp by sea urchins in eastern Canada. J. Fish. Res. Bd Can. 33: $1278-1283$

DeNiro, M. J., Epstein, S. (1978). Influence of diet on the distribution of carbon isotopes in animals. Geochim. cosmochim. Acta 42: 495-506

Findlay, S., Tenore, K. R. (1982). Nitrogen source for a detritivore: Detritus substrate versus associated microbes. Science 218: 371-373

Fry, B., Sherr, E. B. (1984). $\delta^{13} \mathrm{C}$ measurements as indicators of carbon flow in marine and freshwater ecosystems. Contr. mar. Sci. 27: 13-47

Haines, E. B. (1976a). Relation between the stable carbon isotope composition of fiddler crabs, plants, and soils in a salt marsh. Limnol. Oceanogr. 21: 880-883

Haines, E. B. (1976b). Stable carbon isotope ratios in the biota, soils, and tidal water of a Georgia salt marsh. Estuar. coast. mar. Sci. 4: 609-616

Haines, E. B., Montague, C. L. (1979). Food sources of estuarine invertebrates analyzed using ${ }^{13} \mathrm{C} /{ }^{12} \mathrm{C}$ ratios. Ecology 60: 48-56

Johnson, C. R. (1984). Ecology of kelp Laminaria longicruris and its principal grazers in the rocky subtidal of Nova Scotia. Ph. D. thesis, Dalhousie University, Halifax

Kepkay, P. E., Andersen, F. Ø. (1985). Aerobic and anaerobic metabolism of a sediment enriched with Spartina detritus. Mar. Ecol. Prog. Ser. 21: 153-161

Macko, S. A., Lee, W. Y., Parker, P. L. (1982). Nitrogen and carbon isotope fractionation by two species of marine amphipods: laboratory and field studies. J. exp. mar. Biol. Ecol. 63: 145-149

Mann, K. H. (1982). Ecology of coastal waters: a systems approach. Univ, of California Press, Berkeley

Mann, K. H. (in press). The role of detritus at the land-sea boundary. SCOR/IABO/UNESCO/CNRS (France) Symposium on Biogeochemical Processes at the Land-Sea Boundary, October 1984, Roscoff, France

McConnaughey, T., McRoy, C. P. (1979). Food web structure and the fractionation of carbon isotopes in the Bering Sea. Mar. Biol. 53: 257-262

Nixon, S. W. (1980). Between coastal marshes and coastal waters - a review of twenty years of speculation and research on the role of salt marshes in estuarine productivity and water chemistry. In: Hamilton, P., McDonald, K. (ed.) Estuarine and wetland processes. Plenum Press, New York, p. 437-525

Rau, G., Mearns, A. J., Young, D. R., Olson, R. J., Schafer, H. A., Kaplan, I. R. (1983). Animal ${ }^{13} \mathrm{C} /{ }^{12} \mathrm{C}$ correlates with trophic levels in pelagic food webs. Ecology 64: 1314-1318

Robertson, A. I., Mann, K. H. (1982). Population dynamics and life history adaptation of Littorina neglecta Bean in an eelgrass meadow (Zostera marina L.) in Nova Scotia. J. exp. mar. Biol. Ecol. 63: 151-171

Schwinghamer, P., Tan, F. C., Gordon, D. C. (1983). Stable carbon isotope studies on the Pecks Cove mudflat ecosystem in the Cumberland Basin, Bay of Fundy. Can. J. Fish. Aquat. Sci. 40 (Suppl. 1): 262-272

Seiderer, L. J., Newell, R. C., Cook, P. A. (1982). Quantitative significance of style enzymes from two marine mussels (Choromytilus meridionalis Krauss and Perna perna L.) in relation to diet. Mar. Biol. Lett. 3: 257-271

Simenstad, C. A., Wissmar, R. C. $(1985) .8^{13} \mathrm{C}$ evidence of the origins and fates of organic carbon in estuarine and nearshore food webs. Mar. Ecol. Prog. Ser. 22: 141-152

Stephenson, R. L., Tan, F. C., Mann, K. H. (1984). Stable carbon isotope variability in marine macrophytes and its implications for food web studies. Mar. Biol. 81: 223-230

Stuart, V. (1982). Absorbed ration, respiratory costs and resultant scope for growth in the mussel Aulacomya ater (Molina) fed on a diet of kelp detritus of different ages. Mar. Biol. Lett. 3: 289-306

Tan, F. C., Strain, P. M. (1979). Organic carbon isotope ratios in recent sediments in the St. Lawrence estuary and the Gulf of St. Lawrence. Estuar. coast. mar. Sci. 8: 213-225

Tan, F. C., Strain, P. M. (1983). Sources sinks and distribution of organic carbon in the St. Lawrence Estuary, Canada. Geochim. cosmochim. Acta 47: 125-132

Tenore, K. R., Hanson, R. B. (1980). Availability of detritus of different types and ages to a polychaete macroconsumer Capitella capitata. Limnol. Oceanogr. 25: 553-558

Thayer, G. W., Parker, P. L., LaCroix, M. W., Fry, B. (1978). The stable carbon isotope ratio of some components of an eelgrass (Zostera marina) bed. Oecologia (Berl.) 35: 1-12 